\title{
Globalne tezy, lokalne przemilczenia
}

\section{Grzegorz Krzywiec}

Wątki polskie w monumentalnej rozprawie autorstwa Timothy Snydera Skrwawione ziemie nie zajmują szczególnie eksponowanego miejsca [Snyder 2010]. Trudno się temu dziwić. Polska - choć na jej terytorium, jak i w całej wschodniej Europie, odegrały się zbrodnie dwudziestowiecznego ludobójstwa - była ledwie niewielkim trybikiem w globalnej rozgrywce między dwoma europejskimi potęgami: hitlerowskimi Niemcami i sowiecką Rosją. A tego przecież dotyczy w głównej mierze książka Snydera. Jednak sprawy polskie, co dostrzegli także liczni krytycy, przy dokładniejszej lekturze odgrywają rolę niebagatelną. Ilustrują ogólniejsze nastawienie autora. Warto się tej narracji przyjrzeć bliżej.

Odwołania do dziejów Polski znaleźć można już we wstępie, gdzie autor zwraca uwagę, że kwestia polska dla problematyki środkowo- i wschodnio-europejskiej bywała zasadnicza. Snyder pisze m.in.: „Zmieniała ona układ sił w Europie Wschodniej jak żaden inny kraj powstały pod koniec drugiej wojny. [...] Przez samo swoje istnienie stanowiła bufor ograniczający zarówno potęgę rosyjską, jak i niemiecką, przez co Moskwa i Berlin patrzyły na nią bardzo niechętnie”. Dalej Synder pisze już jednak bardziej metaforycznie: „Ideologią Polski byłą niepodległość” [Snyder 2011: 26]. Przy takim założeniu wszystkie inne problemy oraz napięcia schodzą na dalszy plan i amerykański historyk o nich raczej nie wspomina. Wprawdzie rzetelnie dodaje, że Polska pierwszej połowy XX w. była państwem wielonarodowym, ale o tym, że polska niepodległość u swego zarania zaznaczyła się stałymi konfliktami narodowościowymi, począwszy od pogromów antyżydowskich z lat 1918-1919 - wraz z największym w tej części Europy pogromem Iwowskim w listopadzie 1918 r. - już się nie zająknie ani słowem.

Monografia Timothy Snydera w kontekście polskim jest zatem tyleż oryginalną syntezą pewnego problemu w historiografii, co interesującą kompozycją wiele mówiących przemilczeń i niedomówień. Nie będzie chyba wielką przesadą powiedzieć, że jej autor okazał się najlepszym produktem rodzimej polityki historycznej. Badacz z Yale już wcześniej zyskał sobie wśród kolegów opinię historyka osobliwie „polonocentrycznego”, a po Skrawionych ziemiach trudno mu będzie pozbyć się tej etykietki. Wiele istotnych, choć dla zachodniego czytelnika nieczytelnych i niezrozumiałych epizodów i wydarzeń drugiej wojny światowej oraz okresu przed nią i po niej, Snyder, jak nikt inny, stara się wytłumaczyć i wpleść w ogólny opis XX w. Mimo to, jego spojrzenie na polskie dzieje okazuje się wyciągiem ze szkolnego podręcznika do historii.

II Rzeczpospolita w oczach Snydera to prawie ostoja świata zachodniego. Dyskryminacja Żydów i innych mniejszości - w tym przede wszystkim Ukraińców - mieści się, jego zdaniem, w konwencji uprzedzeń, jakie miały być wtedy powszechne. O polskich 
rządowych planach przesiedleń Żydów na Madagaskar napisze nieco eufemistycznie: „władze polskie również przyglądały się Madagaskarowi jako celowi ich [Żydów] potencjalnego przesiedlenia”, zaznaczając od razu, że „przywódcy Polski nie przewidywali wdrożenia [ich] wobec jej pokaźnych mniejszości narodowych” [Snyder 2011: 135]. Zaraz potem zaznacza jednak, że po 1935 r. polscy przywódcy „zajęli w tej sprawie stanowisko zgodne z poglądami nacjonalistycznej prawicy" [Snyder 2011: 135], która zarówno przymus emigracyjny, jak i przemoc fizyczną - rzecz jasna tylko w przypadkach uzasadnionych - propagowała. O tym amerykański autor już nie wspomina. Historykowi, który z perspektywy globalnej patrzy na konfrontację dwóch totalitarnych mocarstw (choć on sam nie używa tej nomenklatury), nieco pogarsza się ostrość widzenia, gdy sięga do przypadków narodowych. Sam tłumaczy, że łatwiej mu o dystans. Zapewne jest w tym i wiele prawdy, i wiele przesady. Bo czy bez zrozumienia tego, co się stało między polską większością a mniejszościami narodowymi w latach trzydziestych da się w ogóle wyjaśnić Jedwabne, rzezie na Wołyniu i szereg innych aktów przemocy? Nazwa „Jedwabne”, która pozostaje symbolem pewnego szerszego zjawiska, w książce w ogóle nie pada.

Jednym z najbardziej karkołomnych zestawień jest porównanie powstania w getcie warszawskim z powstaniem warszawskim. Amerykański historyk pisze między innymi, że więcej Żydów walczyło w powstaniu warszawskim niż w powstaniu w getcie. Zaliczywszy do Żydów Polaków pochodzenia żydowskiego, badacz nie musi być daleki od prawdy. Nie wspomina on jednak, że większość tych powstańców musiało ukrywać swoje żydowskie pochodzenie. Bynajmniej nie wyjaśnia, dlaczego.

Powstanie w getcie warszawskim przypadło na końcową fazę rzezi, eksterminacji i zacierania śladów żydowskości. Powstanie warszawskie było źle pomyślaną i fatalnie politycznie przeprowadzoną akcją wojskową, połączoną z fałszywą geostrategiczną kalkulacją, w wyniku której doszło do klęski, krwawego odwetu i zniknięcia z powierzchni ziemi aglomeracji miejskiej wraz z częścią jej ludności. Porównanie tych dwóch wydarzeń jest samo w sobie nie lada osiągnięciem.

Pisząc o drugiej wojnie światowej, Timothy Snyder nie wyciąga wielu „ciemnych kart” z zachowań społeczności lokalnych wobec Żydów, których na prowincji było zwykle więcej niż w większych miastach. Szerokim łukiem omija np. skalę polskiego szmalcownictwa. Co znamienne, w kwestii lokalnego antysemityzmu nie podaje żadnych danych statystycznych, które gdzie indziej z takim upodobaniem i aptekarskim pedantyzmem przywołuje. A przecież historycy już od lat dysponują licznymi szacunkami.

Niektóre opisy zachowań ludności polskiej wobec Żydów i ich tłumaczenie przez Snydera są szczególnie kuriozalne. Słynny gest przeciągania palcem po gardle odczytuje on jako poinformowanie o nieuniknionej śmierci. W kontekście stosunków polsko-żydowskich autor Skrwawionych ziem prawie w ogóle nie pisze o tzw. trzeciej fali Zagłady, czyli ostatniej fazie eksterminacji Żydów po likwidacji gett, przeprowadzanej rękami ludności miejscowej. Nie jest to problem, który odkryli dopiero Jan Tomasz Gross i Irena Grudzińska-Gross czy 
autorzy z kręgu warszawskiego Centrum Badania Zagłady Żydów, do prac których skądinąd Snyder często sięga. W zaprezentowanym przezeń globalnym schemacie morderczego uścisku dwóch monstrów, miejsca na tego rodzaju wydarzenia brakuje. Niewiele też znajdzie czytelnik informacji o skali ksenofobicznej przemocy zaraz po wojnie - zjawisku w tej części Europy charakterystycznym, a w Polsce ze względu na rozmiar i powszechność wyjątkowym i ciągle wymagającym nowych kluczy interpretacyjnych. W tym erudycyjnym, świetnie udokumentowanym i warsztatowo nienagannym wywodzie czasami coś ważnego się gubi, a niektóre szarże interpretacyjne autora muszą budzić wątpliwości.

Amerykański historyk lubuje się w różnego rodzaju zestawieniach i konfrontacjach statystycznych, co przy jego sugestywnym stylu prowadzi niestety do drobnych konfabulacji lub zgoła zmyśleń. Oto przykład: Snyder wylicza, że mieszkający w 1933 r. w Warszawie „etniczny” Polak miał takie same, lub niewiele się różniące, szanse przeżycia wojny, jak mieszkający w tym czasie w Berlinie Żyd. W polskim kontekście jego wywody można czytać jako rozbudowaną glossę do debat wokół prac Jan Tomasza Grossa. Wypowiedź Snydera współbrzmieć będzie z enuncjacjami najwybitniejszych krytyków autora Sąsiadów i Strachu - Dariusza Stoli, Antoniego Sułka czy Marcina Zaremby.

O pierwszych latach komunizmu w Polsce Snyder pisze w dość osobliwy sposób. Jeśli czytać niektóre fragmenty dosłownie, jak np. ten o Bolesławie Bierucie, który stanowił "gojowskie oblicze” triumwiratu polskiej partii komunistycznej [Snyder 2011: 388], i cały poprzedzający go wywód, to albo historyk się w tym miejscu się zapędzit, albo z pomocą tłumacza chciałby dotrzeć do nie tak znowu małej części polskich czytelników, przeświadczonych o powojennych rządach „żydokomuny”.

Wszystko wskazuje na to, że do powszechnego obiegu książka Timothy Snydera trafi jako lepiej podbudowane i przemyślane świadectwo wschodnioeuropejskiej opowieści martyrologicznej. Rzecz jasna, zarówno styl, rozmach oraz tempo narracji budzą podziw i respekt. Autor, który wcześniej nie zajmował się w sposób systematyczny ani nazizmem, ani systemem sowieckim, napisał książkę, która wywoła niejedną dyskusję. Jednak trudno uciec od wrażenia, że amerykański historyk w chwalebnym zamyśle syntetycznego połączenia zachodnio- i wschodnioeuropejskich narracji o doświadczeniu XX w. przedstawił ułatwione wersje narodowych historii państw regionu. I wybrał tym samym drogę na skróty. W sprawach polskich skopiował powtarzane w rodzimych opowieściach refreny podręcznikowe zarówno o II Rzeczpospolitej, wojnie światowej, jak i okresie zaraz po wojnie. Takie ujęcia historii są bezpieczne, „słuszne” i w zasadzie niekontrowersyjne.

Próba budowania symetrii między losem Żydów a prześladowaniami innych grup narodowych w trakcie drugiej wojny światowej nie służy książce, bo los Żydów pozostaje wyjątkowy bynajmniej nie ze względu na liczby, od których autor nie może się oderwać. Żeby zintegrować opowieść o Shoah z doświadczeniem narodów wschodnioeuropejskich nie można przemilczać bądź marginalizować świadectw niechlubnej przeszłości tych ostatnich, i to nie tylko w relacjach z Żydami. Przeciwnie: trzeba stawić im czoła. W Skrwawionych ziemiach tego zabrakło. 


\section{Bibliografia}

Snyder Timothy, 2010, Bloodlands. Europe between Hitler and Stalin, New York: Basic Books.

Snyder Timothy, 2011, Skrwawione ziemie. Europa między Hitlerem a Stalinem, tłum. Bartłomiej Pietrzyk, Warszawa: Świat Książki. 